\title{
Drought responses by individual tree species are not often correlated with tree species diversity in European forests
}

\author{
David I. Forrester ${ }^{1 *}$, Damien Bonal ${ }^{2}$, Seid Dawud ${ }^{3}$, Arthur Gessler ${ }^{4,5}$, André Granier ${ }^{2}$, \\ Martina Pollastrini ${ }^{6}$ and Charlotte Grossiord ${ }^{7}$ \\ ${ }^{1}$ Chair of Silviculture, Faculty of Environment and Natural Resources, Freiburg University, Tennenbacherstr. 4, 79108 \\ Freiburg, Germany; ${ }^{2}$ INRA, UMR EEF INRA-Université de Lorraine, 54280 Champenoux, France; ${ }^{3}$ Department of \\ Forestry, College of Agriculture, Wollo University, P.O. Box 1145, Dessie, Ethiopia; ${ }^{4}$ Swiss Federal Institute for \\ Forest, Snow and Landscape Research, 8903 Birmensdorf, Switzerland; ${ }^{5}$ Berlin-Brandenburg Institute of Advanced \\ Biodiversity Research, 14195 Berlin, Germany; ${ }^{6}$ Department of Agri-Food Production and Environmental Science, \\ University of Florence, Piazzale delle Cascine 28, 50144 Florence, Italy; and ${ }^{7}$ Earth and Environmental Sciences \\ Division, Los Alamos National Laboratory, Los Alamos, NM 87545, USA
}

\begin{abstract}
Summary
1. Drought frequency and intensity are predicted to increase in many parts of the Northern Hemisphere and the effects of such changes on forest growth and tree mortality are already evident in many regions around the world. Mixed-species forests and increasing tree species diversity have been put forward as important risk reduction and adaptation strategies in the face of climate change. However, little is known about whether the species interactions that occur in diverse forests will reduce drought susceptibility or water stress.

2. In this study, we focused on the effect of drought on individual tree species $(n=16)$ within six regions of Europe and assessed whether this response was related to tree species diversity and stand density, and whether community-level responses resulted from many similar or contrasting species-level responses. For each species in each plot, we calculated the increase in carbon isotope composition of latewood from a wet to a dry year $\left(\Delta \delta^{13} \mathrm{C}\right)$ as an estimate of its drought stress level.

3. When significant community-level relationships occurred (three of six regions), there was only one species within the given community that showed a significant relationship (three of 25 species-region combinations), showing that information about a single species can be a poor indicator of the response of other species or the whole community.

4. There were many two-species mixtures in which both species were less water-stressed compared with their monocultures, but also many mixtures where both species were more stressed compared with their monocultures. Furthermore, a given species combination responded differently in different regions.

5. Synthesis and applications. Our study shows that drought stress may sometimes be reduced in mixed-species forests, but this is not a general pattern, and even varies between sites for a given combination. The management or prediction of drought stress requires consideration of the physiological characteristics of the mixed species, and how this complements the waterrelated climatic and edaphic features of the site, rather than species richness.
\end{abstract}

Key-words: carbon isotopes, climate change, competition, complementarity, drought, European mixed-species forest, facilitation, forest diversity, species interaction, water stress

\footnotetext{
*Correspondence author.

E-mail: david.forrester@waldbau.un-ifreiburg.de
} 


\section{Introduction}

Mixed-species forests are viewed as an important component of risk reduction and adaptation strategies for forest ecosystems in the face of global change (Messier, Puettmann \& Coates 2013). Many studies have shown that mixed-species forests can be more productive than monocultures (Paquette \& Messier 2011; Zhang, Chen \& Reich 2012; Forrester \& Bauhus 2016) and some have also shown that they can be more resistant and resilient to climate extremes (Lebourgeois et al. 2013; Pretzsch, Schütze \& Uhl 2013). However, faster growing forests generally have greater evapotranspiration than slower growing forests (Law et al. 2002). Similarly, when the growth of a given species increases in mixtures compared with monocultures, the transpiration of that species also increases in the mixtures (Forrester 2015). If evapotranspiration is greater in mixtures, it could potentially lead to greater water stress of some or all species during drought periods (Schume, Jost \& Hager 2004; Grossiord et al. 2014b), which conflicts with the strategic use of mixtures to reduce forest water stress. To understand and to use these dynamics, it is necessary to consider two factors that can be influenced by species interactions and potentially affect the intensity of drought stress.

The first is that, for a given stand density (basal area, sapwood area, leaf area, etc.), the species interactions may help reduce water stress, such as via facilitative processes including hydraulic lift and more favourable canopy microclimates, or via a reduction in competition due to temporal or spatial stratification in soil water uptake and use (Forrester \& Bauhus 2016). These can be broadly referred to as species complementarity. However, a second factor relates to the fact that these species interactions could result in an increase in growth and evapotranspiration in mixtures (Kunert et al. 2012; Forrester 2015), which could potentially result in greater water stress during hot or dry periods if soil water is depleted. The water stress of a given species may then be expected to increase with stand density (in terms of basal area, biomass, leaf area index), which is likely to be higher in mixtures if they are growing faster than monocultures, unless thinning intensities are also greater in mixtures.

It is noted that many mixtures are not more productive than the respective monocultures, but when mixtures are more productive (and with greater evapotranspiration), this density effect might be expected.

Reducing stand density by thinning can initially increase the availability of water for the remaining trees and has been discussed as an option to mitigate drought impacts (Cescatti \& Piutti 1998; Laurent, Antoine \& Joel 2003; Martín-Benito et al. 2010; Sohn et al. 2013). For instance, many studies have shown that increases in droughtinduced mortality can be related to increases in stand density (Allen et al. 2010); however, drought-related mortality was also found to be unrelated to differences in stand density (van Mantgem \& Stephenson 2007). The mitigation effects of density control by thinning are also not straight forward and appear to depend on the time since thinning as well as the resulting stand structure and tree hydraulic architecture (Sohn et al. 2013). These contrasting effects of stand density and thinning indicate that stand density in relation to tree species diversity is important to consider when examining the drought stress of forests.

Direct measurements of water pools and fluxes are labour-intensive or require intensive instrumentation, which restricts the number of sites and species included in studies comparing these pools and fluxes in mixtures and monocultures (Forrester 2015; Volkmann et al. 2016). Therefore, complementary studies have used indirect methods to estimate the effect of drought on tree water status, particularly stable carbon isotope composition $\left(\delta^{13} \mathrm{C}\right)$. The variation in $\delta^{13} \mathrm{C}$ of tree rings between a wet and a dry year $\left(\Delta \delta^{13} \mathrm{C}\right)$ can be used as a proxy for tree water stress (Saurer, Siegenthaler \& Schweingruber 1995) and used to examine whether water stress increases or decreases along gradients of tree species diversity and/or on different sites (Grossiord et al. 2014a,b; Metz et al. 2016). A Europeanwide study that included sixteen species showed that water stress at the community level declined with increasing tree species diversity in two forest types (temperate beech forests and Thermophilous deciduous forests), increased with diversity in Boreal forests, while there was no relationship in three other forests types including hemiboreal, mountainous beech and Mediterranean forests (Grossiord et al. 2014a,b). This study concluded that there does not appear to be any general relationship between community-level drought stress and diversity, so drought stress will often not be reduced by increasing the diversity of forests. Rather than simply increasing species diversity, it appears to be more important to combine species with complementary characteristics, in terms of their water-related interactions, and that also suit the climatic and edaphic conditions at the site (Forrester 2014).

In contrast, a study focusing on Fagus sylvatica L. suggested that this species was less stressed when growing in mixtures than in monocultures (Metz et al. 2016). Most of the mixtures had lower stand densities (competition indices) than the monocultures, so it was not clear whether this was a species mixing effect or a density effect. Metz et al. (2016) concluded that 'the systematic formation of mixed stands tends to be an appropriate silvicultural measure to mitigate the effects of global warming and droughts on growth patterns of Fagus sylvatica'. This is a strong and potentially very useful conclusion for foresters. However, it contrasts with those of other studies with F. sylvatica in Central Europe that indicated that $F$. sylvatica may actually suffer more drought stress when mixed with species that exhaust water reserves early in the summer (e.g. Tilia sp. or Quercus sp. Gebauer, Horna \& Leuschner 2012; Mölder \& Leuschner 2014), or found that F. sylvatica may cause other species (e.g. P. abies (L.) Karst.) more water stress during droughts (Schume, Jost \& Hager 2004) thereby reducing the stability and productivity of the mixtures compared with the 
monocultures. Another study showed that F. sylvatica trees were more resistant and resilient to drought (in terms of growth response) in mixtures with Quercus petraea or Picea abies, while the resistance and resilience of those species were not significantly different in mixtures with F. sylvatica compared with monocultures (Pretzsch, Schütze \& Uhl 2013). These contrasting responses indicate that to predict the drought susceptibility of forests it is important to know whether all species are likely to benefit from the mixture or whether only some benefit (e.g. F. sylvatica) at the expense of other species. Similarly, it is important to know whether the whole community (total or mean of all species) will be less stressed as a mixture or a monoculture, as opposed to only a single species within the community (e.g. F. sylvatica).

This requires information about all species within the mixture, and also the separation of the effects of species composition from potentially related factors that can influence drought stress, such as stand density, which is likely to increase with diversity if productivity increases with diversity. In this study, we used data of individual species tree-ring $\delta^{13} \mathrm{C}$ from six regions in Europe and sixteen species to test whether these forests show any general relationships between the water stress of a given species, species composition and stand density.

Specifically, our objectives were to determine (i) whether significant relationships at the community level between drought stress and diversity are associated with similar species-level relationships by all, several or only a single species within the community; (ii) when there is no relationship at the community level, are all species-level relationships also insignificant or do they contrast and counterbalance each other to result in a neutral community-level relationship. Lastly, while stand density (basal area) was only weakly related to diversity at each region, density did vary between plots; therefore, we also examined whether (iii) the drought stress of each species was related to stand density.

\section{Materials and methods}

\section{EXPERIMENTAL SITES}

The study was done in a European permanent plot network that was established in 2011 (FunDivEUROPE; Baeten et al. 2013). The network includes six regions that are representative of major European forest types (Table 1). Within each region, 21 to 42 plots $(30 \mathrm{~m} \times 30 \mathrm{~m})$ were established, resulting in a total of 184 . A total of 16 different target tree species occurred within the plots. Some species occurred in more than one region, but none occurred in all regions (Table 1). The tree species richness of the plots ranged from 1 to 3 in Finland and Spain, 1 to 4 in Romania and Germany and 1 to 5 in Italy and Poland. The target species were the most common species within the given region. Within each region, each target tree species was represented at all richness levels, and when possible, there were two replicates per species combination per region. There were only weak or no relationships between tree species richness and stand basal area in each region (Fig. S7 in Jucker, Bouriaud \& Coomes 2015).
Three additional criteria were used when establishing the plots (FunDivEUROPE; Baeten et al. 2013). First, all plots were in mature forests that had received minimal management during the past decade or longer. Second, within a region, all plots were at a comparable developmental stage and had similar topography, soil and bedrock properties. Third, the relative abundance of each target species within a given plot was as similar as possible, while the presence of non-target species was usually restricted to $<5 \%$ of the total plot basal area.

\section{STAND CHARACTERISTICS}

This study focuses on the species-level responses using the same data that were used to examine community-level responses in two previous studies (Grossiord et al. 2014a,b), where additional detail about the methodology is provided. The stem diameter at $1.3 \mathrm{~m}$ was measured for all trees with diameter $\geq 7.5 \mathrm{~cm}$ in 2011 and 2012. These were used to calculate the basal area $\left(\mathrm{m}^{2} \mathrm{ha}^{-1}\right)$ of each species (i) in each plot $\left(\mathrm{BA}_{\mathrm{i}}\right)$ and hence the total plot basal area $\left(\mathrm{BA}_{\mathrm{T}}\right)$. Tree species richness was simply the number of target tree species within a given plot. Tree species diversity was quantified using Shannon's index (Shannon 1948) based on the basal area of each target species within a plot using eqn 1 .

Tree species diversity $=-\sum_{i=1}^{n} \frac{\mathrm{BA}_{\mathrm{i}}}{\mathrm{BA}_{\mathrm{T}}} \ln \left(\frac{\mathrm{BA}_{\mathrm{i}}}{\mathrm{BA}_{\mathrm{T}}}\right)$ eqn 1

where $n$ is the number of target tree species in the plot. While the relative abundance of each target species within a given plot was as similar as possible, there was still some variability. Therefore, Shannon's index was used to account for the evenness of the species mixing.

To account for the effects of irradiance, soil nutrient availability and soil moisture on $\delta^{13} \mathrm{C}$, the effects of irradiance were approximated using plot leaf area index (LAI) and those of soil nutrient availability were approximated using soil $\mathrm{C} / \mathrm{N}$ ratio. In addition, stand basal area was used to approximate competition for all resources. Stand basal area and LAI were also used to check that species richness and diversity were not confounded with stand density, which can influence the productivity (and possibly related ecosystem functions) more than richness and diversity in European forests (Vilà et al. 2013). The measurements of LAI and soil C/N ratio are described in Appendix S1.

\section{QUANTIFICATION OF TREE WATER STRESS}

The stomatal response of plants to soil water deficit is related to the molar ratio of the two naturally occurring $\mathrm{C}$ isotopes $\left({ }^{13} \mathrm{C} /{ }^{12} \mathrm{C}\right)$ in the plant material that was produced during the period of water deficit (Dupouey et al. 1993; Warren, McGrath \& Adams 2001; Ferrio et al. 2003), expressed as $\delta^{13} \mathrm{C}(\%)$. The variation in $\delta^{13} \mathrm{C}$ of plant material that was produced during a given wet period (i.e. reference year) and a drought period can therefore be used as an index of the physiological response to soil drought. We used the difference in the $\delta^{13} \mathrm{C}$ of latewood within growth rings of the tree stems between a year with very wet summer conditions and a year with extreme drought conditions (Grossiord et al. 2014a,b). This variation, $\Delta \delta^{13} \mathrm{C}(\%)$, was calculated for each species in each plot as $\delta^{13} \mathrm{C}_{\mathrm{dry}}-\delta^{13} \mathrm{C}_{\text {wet. }}$. While $\delta^{13} \mathrm{C}$ can be influenced by any factors that influence stomatal conductance, including radiation, soil fertility (Farquhar, Ehleringer \& 
Table 1. Stand characteristics for each of the six regions (modified from Grossiord et al. 2014a,b)

\begin{tabular}{|c|c|c|c|c|c|c|}
\hline Stand characteristic & Region & & & & & \\
\hline Main forest type & Boreal & Hemiboreal & $\begin{array}{l}\text { Temperate } \\
\text { beech }\end{array}$ & $\begin{array}{l}\text { Mountainous } \\
\text { beech }\end{array}$ & $\begin{array}{l}\text { Thermophilous } \\
\text { deciduous }\end{array}$ & $\begin{array}{l}\text { Continental- } \\
\text { Mediterranean }\end{array}$ \\
\hline Country & Finland & Poland & Germany & Romania & Italy & Spain \\
\hline Forest name & North Karelia & Bialowieza & Hainich & Râsca & Colline Metallifere & Alto Tajo \\
\hline Latitude/Longitude & $62 \cdot 60^{\circ}, 29 \cdot 76^{\circ}$ & $52.72^{\circ}, 23.95^{\circ}$ & $51 \cdot 10^{\circ}, 10 \cdot 51^{\circ}$ & $47.32^{\circ}, 26.03^{\circ}$ & $43 \cdot 27^{\circ}, 11 \cdot 26^{\circ}$ & $40.77^{\circ},-1.95^{\circ}$ \\
\hline $\begin{array}{l}\text { MAT }\left({ }^{\circ} \mathrm{C}\right) \\
\operatorname{MAP}(\mathrm{mm})\end{array}$ & $2 \cdot 1,700$ & $6 \cdot 9,627$ & $6 \cdot 8,775$ & $6 \cdot 8,800$ & $13 \cdot 0,850$ & $10 \cdot 2,499$ \\
\hline Soil depth & Medium & Deep & Deep & Medium & Deep & Shallow \\
\hline $\begin{array}{l}\text { Altitude } \\
\text { range (m a.s.l.) }\end{array}$ & $80-200$ & $135-185$ & $500-600$ & $600-1000$ & $260-525$ & $960-1400$ \\
\hline $\begin{array}{l}\text { Highest tree } \\
\text { species richness }\end{array}$ & 3 & 5 & 4 & 4 & 5 & 3 \\
\hline \multicolumn{7}{|l|}{ Target species } \\
\hline Abies alba (Aa) & & & & $\mathrm{x}$ & & \\
\hline $\begin{array}{l}\text { Acer } \\
\text { pseudoplatanus (Ap) }\end{array}$ & & & $\mathrm{x}$ & $\mathrm{x}$ & & \\
\hline Betula pendula $(\mathrm{Bp})$ & $\mathrm{x}$ & $\mathrm{x}$ & & & & \\
\hline Carpinus betulus $(\mathrm{Cb})$ & & $\mathrm{x}$ & & & & \\
\hline Castanea sativa (Cs) & & & & & $\mathrm{x}$ & \\
\hline Fagus sylvatica (Fs) & & & $\mathrm{x}$ & $\mathrm{x}$ & & \\
\hline Fraxinus excelsior $(\mathrm{Fe})$ & & & $\mathrm{x}$ & & & \\
\hline Ostrya carpinifolia $(\mathrm{Oc})$ & & & & & $\mathrm{x}$ & \\
\hline Picea abies $(\mathrm{Pa})$ & $\mathrm{x}$ & $\mathrm{x}$ & $\mathrm{x}$ & $\mathrm{x}$ & & \\
\hline Pinus nigra $(\mathrm{Pn})$ & & & & & & $\mathrm{x}$ \\
\hline Pinus sylvestris $(\mathrm{Ps})$ & $\mathrm{x}$ & $\mathrm{x}$ & & & & $\mathrm{x}$ \\
\hline Quercus cerris (Qc) & & & & & $\mathrm{x}$ & \\
\hline Quercus faginea (Qf) & & & & & & $\mathrm{x}$ \\
\hline Quercus ilex (Qi) & & & & & $\mathrm{x}$ & \\
\hline Quercus petraea $(\mathrm{Qp})$ & & & $\mathrm{x}$ & & $\mathrm{x}$ & \\
\hline Quercus robur $(\mathrm{Qr})$ & & $\mathrm{x}$ & & & & \\
\hline Total number of plots & 26 & 42 & 35 & 26 & 34 & 21 \\
\hline $\begin{array}{l}\text { Number of plots per } \\
\text { species diversity level } \\
\text { (ranked from } \\
\text { monoculture to } \\
\text { highest richness level) }\end{array}$ & $10 / 12 / 4$ & $10 / 9 / 11 / 10 / 2$ & $7 / 8 / 15 / 5$ & $8 / 10 / 7 / 1$ & $10 / 8 / 8 / 7 / 1$ & $9 / 9 / 3$ \\
\hline $\begin{array}{l}\text { Mean stand density } \\
\pm \mathrm{SE}\left(\text { tree } \mathrm{ha}^{-1}\right)\end{array}$ & $890 \pm 51$ & $499 \pm 39$ & $533 \pm 51$ & $535 \pm 31$ & $759 \pm 53$ & $910 \pm 95$ \\
\hline $\begin{array}{l}\text { Mean stand basal } \\
\text { area } \pm \mathrm{SE}\left(\mathrm{m}^{2} \mathrm{ha}^{-1}\right)\end{array}$ & $20 \cdot 9 \pm 0 \cdot 8$ & $32 \cdot 5 \pm 1$ & $32 \cdot 5 \pm 1 \cdot 6$ & $45 \cdot 9 \pm 2 \cdot 2$ & $24 \cdot 2 \pm 0 \cdot 6$ & $24 \cdot 2 \pm 2$ \\
\hline $\begin{array}{l}\text { Mean leaf area } \\
\text { index } \pm \mathrm{SE}\left(\mathrm{m}^{2} \mathrm{~m}^{-2}\right)\end{array}$ & $2 \cdot 8 \pm 0 \cdot 2$ & $5 \cdot 4 \pm 0 \cdot 2$ & $6 \cdot 4 \pm 0 \cdot 2$ & $5 \cdot 8 \pm 0 \cdot 1$ & $3 \cdot 9 \pm 0 \cdot 1$ & $1.9 \pm 0 \cdot 1$ \\
\hline Mean soil $\mathrm{C} / \mathrm{N} \pm \mathrm{SE}$ & $23 \cdot 8 \pm 0 \cdot 6$ & $16 \cdot 5 \pm 0 \cdot 4$ & $12 \cdot 3 \pm 0 \cdot 2$ & $12 \cdot 9 \pm 0 \cdot 2$ & $18 \cdot 6 \pm 0 \cdot 7$ & $21 \cdot 3 \pm 1 \cdot 6$ \\
\hline $\begin{array}{l}\text { Mean water stress } \\
\text { index } \pm \text { SE } \\
(1997-2010)^{*}\end{array}$ & $0 \cdot 5 \pm 0 \cdot 3$ & $9 \cdot 6 \pm 3 \cdot 7$ & $29 \cdot 5 \pm 5 \cdot 3$ & $18 \cdot 2 \pm 5 \cdot 1$ & $35 \cdot 7 \pm 3 \cdot 7$ & $21 \cdot 2 \pm 5 \cdot 4$ \\
\hline $\begin{array}{l}\text { Water stress index } \\
\text { of wet year (year)* }\end{array}$ & 0 (2004) & $0(2002)$ & $0 \cdot 9(2002)$ & $5 \cdot 2(2001)$ & $2 \cdot 4(2002)$ & $0(2002)$ \\
\hline $\begin{array}{l}\text { Water stress index } \\
\text { of dry year (year)* }\end{array}$ & $1.5(2006)$ & $44 \cdot 6(2010)$ & $68.4(2003)$ & $46 \cdot 6(2003)$ & $50 \cdot 1(2003)$ & $46 \cdot 4(2001)$ \\
\hline
\end{tabular}

*The calculation of the water stress index is described in the Materials and Methods and Grossiord et al. (2014b).

Hubick 1989; Warren, McGrath \& Adams 2001; Ferrio, Voltas \& Araus 2003) and genetics (Brendel et al. 2002), it was assumed that the main factor that varies between the wet and dry year is the water-related stress (see Grossiord et al. 2014a,b for more details). A higher $\Delta \delta^{13} \mathrm{C}$, and hence a greater increase in $\delta^{13} \mathrm{C}$ in the dry year, indicates a stronger stomatal response and thus a higher level of drought stress; a $\Delta \delta^{13} \mathrm{C}$ of zero would indicate that there was no change in $\delta^{13} \mathrm{C}$ in response to drought and hence no drought-induced stress. The latewood was sampled because the $\delta^{13} \mathrm{C}$ of earlywood can be influenced by the remobilization of photosynthates from previous growing seasons (Offermann et al. 2011) or favourable spring weather, whereas the latewood is more likely to be affected by droughts that occur in the later part of the growing season. While $\delta^{13} \mathrm{C}$ analyses are sometimes performed on the cellulose fraction of the wood, cellulose and bulk material produce highly correlated signals (Loader, Robertson \& McCarroll 2003) and the latter was used in this study. 
Wood cores for $\delta^{13} \mathrm{C}$ measurements were collected by randomly selecting six trees per species in monocultures and three trees per species in mixed-species plots from the 10 largest diameter trees to ensure that only dominant and co-dominant trees were selected. The larger size classes were used to avoid the confounding effects of shading on the $\delta^{13} \mathrm{C}$ of suppressed trees (Ferrio, Voltas \& Araus 2003). A total of 1390 trees were sampled across the six regions and one 5-mm-diameter core was extracted from the southern side of each tree at a height of $1.3 \mathrm{~m}$. For each core, the latewood for the selected years (wet vs. dry) was separated from the earlywood using a scalpel. The latewood samples for a given year (wet or dry), a given species and a given plot, were bulked to obtain enough material for carbon isotope analysis to ensure sample homogeneity and to reduce the cost of the analyses. While this is a relatively low sample number, the replication is adequate due to the strong imprint of environmental signals on tree-ring carbon isotope composition (Peñuelas et al. 2008). This procedure is described in detail by Grossiord et al. (2014a,b).

The growing seasons with non-limiting soil water conditions and those with severe soil drought were selected using a water balance model to estimate the daily relative extractable water for each region between 1997 and 2010. The dry year used for $\delta^{13} \mathrm{C}_{\mathrm{dry}}$ was randomly selected from the three driest years between 1997 and 2010. The wet year used for $\delta^{13} \mathrm{C}_{\text {wet }}$ was randomly selected from the years with a low water stress index. This procedure is described in detail in Appendix S1.

\section{STATISTICAL ANALYSES}

The effect of stand variables on $\Delta \delta^{13} \mathrm{C}$ was examined using linear regression analyses. Stand variables included tree species richness, tree species diversity, stand basal area, LAI and soil $\mathrm{C} / \mathrm{N}$ ratio. The labour-intensive aspect of the data collection and the number of regions, species and tree richness levels did not allow for a high level of replication. While multiple linear regression could be used to account for all stand variables in a single model for each given species, we avoided fitting multiple regressions because this would result in low ratios of sample sizes to the number of variables (often ratios of less than 10) (Clarke \& Wheaton 2007; Bolker et al. 2009). We therefore examined the effects of each variable separately. All statistical analyses were carried out using $\mathrm{R}$ software version 3.2.1 (R Core Team 2015)

\section{Results}

\section{RELATIONSHIPS BETWEEN RICHNESS OR DIVERSITY AND $\Delta \delta^{13} \mathrm{C}$}

Tree species richness and diversity generally had similar effects on the species-level $\Delta \delta^{13} \mathrm{C} . \Delta \delta^{13} \mathrm{C}$ decreased with increasing diversity or richness for C. sativa in the Thermophilous deciduous forests of Italy (Figs 1 and S1, Tables S1 and S2 in Supporting information). It also decreased with increasing diversity (but not richness) for $F$. sylvatica in the temperate beech forests of Germany. In contrast, $\Delta \delta^{13} \mathrm{C}$ increased for $P$. abies with richness and diversity in the Boreal forests of Finland (Figs 1 and S1).
$\Delta \delta^{13} \mathrm{C}$ also increased with richness for $F$. sylvatica in the mountainous beech forests in Romania (Fig. S1d), which is the opposite pattern for F. sylvatica in Germany (Fig. 1c). There were no significant relationships between $\Delta \delta^{13} \mathrm{C}$ and diversity in the other two forest types, hemiboreal forests in Poland and Mediterranean forests in Spain.

To indicate why there were so few significant relationships with richness and diversity (three of 25 species-region combinations), Fig. 2 compares the $\Delta \delta^{13} \mathrm{C}$ of each species in its monoculture with the $\Delta \delta^{13} \mathrm{C}$ of the same species when it was in a two-species mixture. While there is no statistical power to test for the significance of the differences, the rankings are used here to interpret the relationships between $\Delta \delta^{13} \mathrm{C}$ and diversity or richness. For many species, the monocultures were not the most stressed stands, and in the Boreal forests of Finland, all species were actually less stressed in monocultures. The variability in the ranking of monocultures and two-species mixtures for different species within a given region indicates that correlations between $\Delta \delta^{13} \mathrm{C}$ and richness or diversity will be reduced because the positive effects on water stress in some mixtures are often offset by negative effects on water stress in other mixtures.

The two species for which drought stress declined with increasing diversity ( $F$. sylvatica in Germany and $C$. sativa in Italy) were also examples where monocultures were more stressed than all two-species mixtures containing those species (Fig. 2). However, this situation was not enough to result in a general positive diversity effect because there were also other species where monocultures were more stressed than all two-species mixtures, but there was no diversity effect (e.g. B. pendula in Poland or Q. cerris in Italy). Figure 2 also shows that there were no single species that were consistently more stressful to all other species within a given site.

\section{RELATIONSHIPS BETWEEN BASAL AREA, LEAF AREA INDEX OR SOIL C/N AND $\Delta \delta^{13} \mathrm{C}$}

The other stand characteristics often varied widely between plots within a given region, but they were rarely correlated with $\Delta \delta^{13} \mathrm{C}$. Stand basal area was negatively correlated with $\Delta \delta^{13} \mathrm{C}$ for $B$. pendula in the hemiboreal forests of Poland (Fig. S2, Table S3). In the same forests, the $\Delta \delta^{13} \mathrm{C}$ was negatively correlated with LAI for Q. robur (Fig. S3, Table S4). This indicates that these species actually became less stressed as stand basal area or LAI increased. The $\mathrm{C} / \mathrm{N}$ of soil was positively correlated with $\Delta \delta^{13} \mathrm{C}$ for $B$. pendula in the Boreal forests of Finland, while it was negatively correlated with the $\Delta \delta^{13} \mathrm{C}$ of $P$. abies in the mountainous beech forests of Romania (Fig. S4, Table S5). There were no other significant relationships between stand variables and $\Delta \delta^{13} \mathrm{C}$ for the other species in any region. 

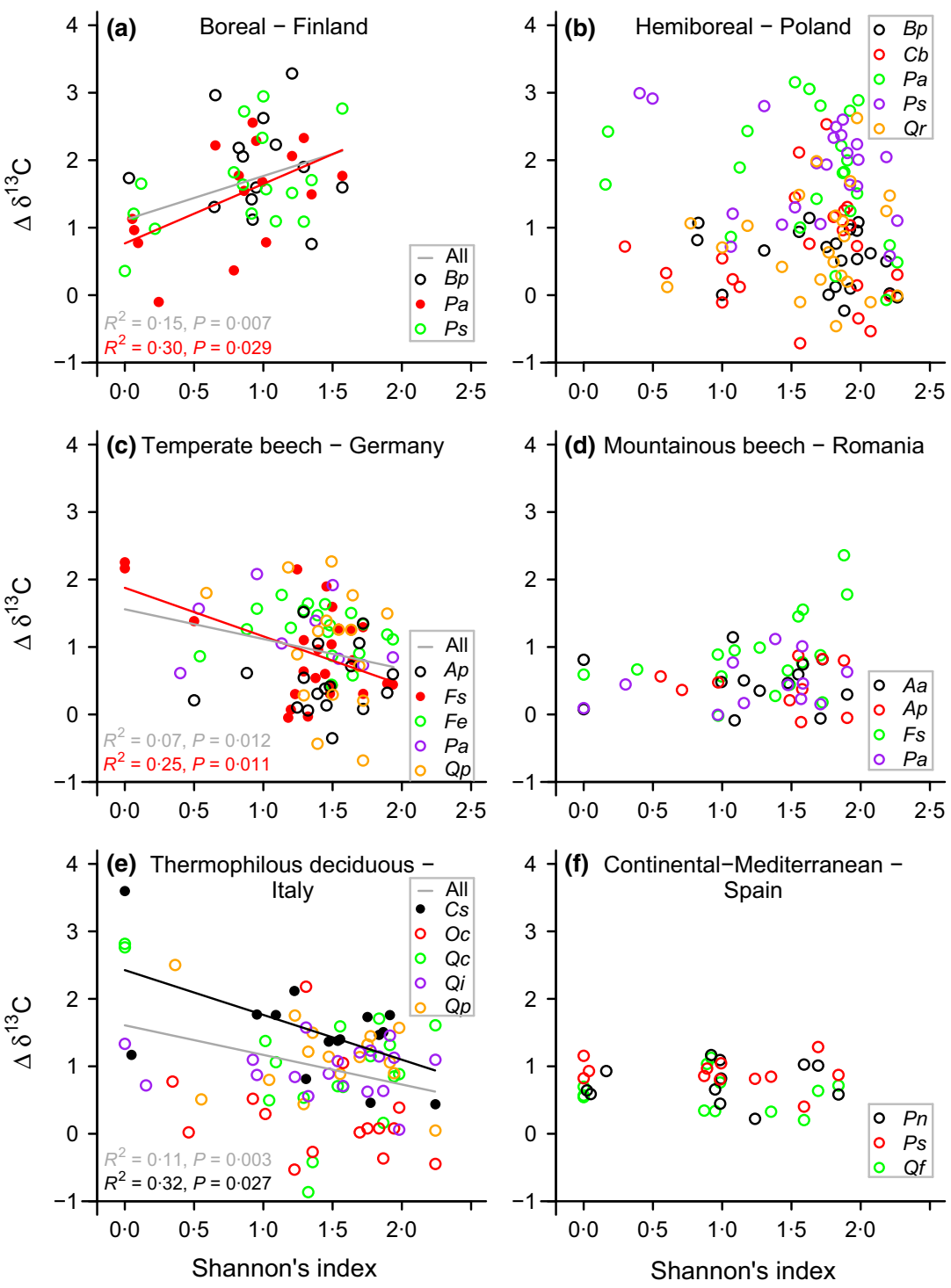

Fig. 1. Increase in the species-specific carbon isotope composition in a dry year, compared with a wet year $\left(\Delta \delta^{13} \mathrm{C}, \%\right)$, in relation to tree species diversity, for each region. Diversity is quantified using Shannon's index. Species codes are the same as in Table 1. The fitted lines show the statistically significant relationships $(P<0.05)$. The grey lines in (a), (c) and (e) are fitted for all species combined. The corresponding $R^{2}$ and $P$ values are provided using the same colour as the lines. There were no significant relationships in (b), (d) or (f).

\section{Discussion}

\section{SPECIES IDENTITY OR SPECIES RICHNESS EFFECTS}

This study shows that the community-level diversity patterns, which were significant in three of the six regions (Grossiord et al. 2014a,b), were mirrored by only one of the species within each given community, and often the relationships for those species were not strong. In the temperate beech forests of Germany, water stress declined in mixtures only because F. sylvatica was less droughtstressed. In the Thermophilous deciduous forests of Italy, stress declined in mixtures only because $C$. sativa was less stressed, and in the Boreal forests of Finland, stress increased in mixtures because $P$. abies was more stressed. There were no community-level relationships in the hemiboreal forests in Poland or the Mediterranean forests in Spain because there were no significant relationships for any of the individual tree species within those communities. There was also no community-level relationship in the mountainous beech forests of Romania, despite a significant relationship for F. sylvatica, because the other species showed no significant relationships.

This variability in species responses within a given stand is consistent with most previous studies that directly measured water pools and fluxes in mixtures; the community-level response is the average of different responses by each species within the community. For example, in some stands there is no clear mixing effect for any species (Moore, Bond \& Jones 2011; Grossiord et al. 2013), in others each species may have greater transpiration per tree (Forrester et al. 2010; Kunert et al. 2012), and in others some species may have greater transpiration or interception of precipitation at the expense of other species (Schume, Jost \& Hager 2004; Gebauer, Horna \& Leuschner 2012). Even for a given species, the mixing effect on water fluxes is the average response of different cohorts or size classes within the stand, such that only some of the trees of that species may be responsible for its response (Forrester 2015). 
Fig. 2. Increase in carbon isotope composition from dry years to wet years in the monocultures and two-species mixtures $\left(\Delta \delta^{13} \mathrm{C}, \%\right.$ ) in Finland (a), Poland (b), Germany (c), Romania (d), Italy (e) and Spain (f). The $x$-axes show the competing species and the data points show the $\Delta \delta^{13} \mathrm{C}$ of each target species. Filled circles show when the target species was growing in monoculture, while open circles indicate mixtures. The lines connect points for a given species. Each point represents a bulked sample taken from six (monocultures) or three (mixtures) trees per species combination. Within a given country, the species ranking, in terms of $\Delta \delta^{13} \mathrm{C}$, varies between competing species indicating that no species was consistently more stressed than the other species in the given country, with the exception of $Q$. petraea in Germany (c) and P. sylvestris in Spain (f), which always exhibited more water stress than all other species in the stands where they occurred.
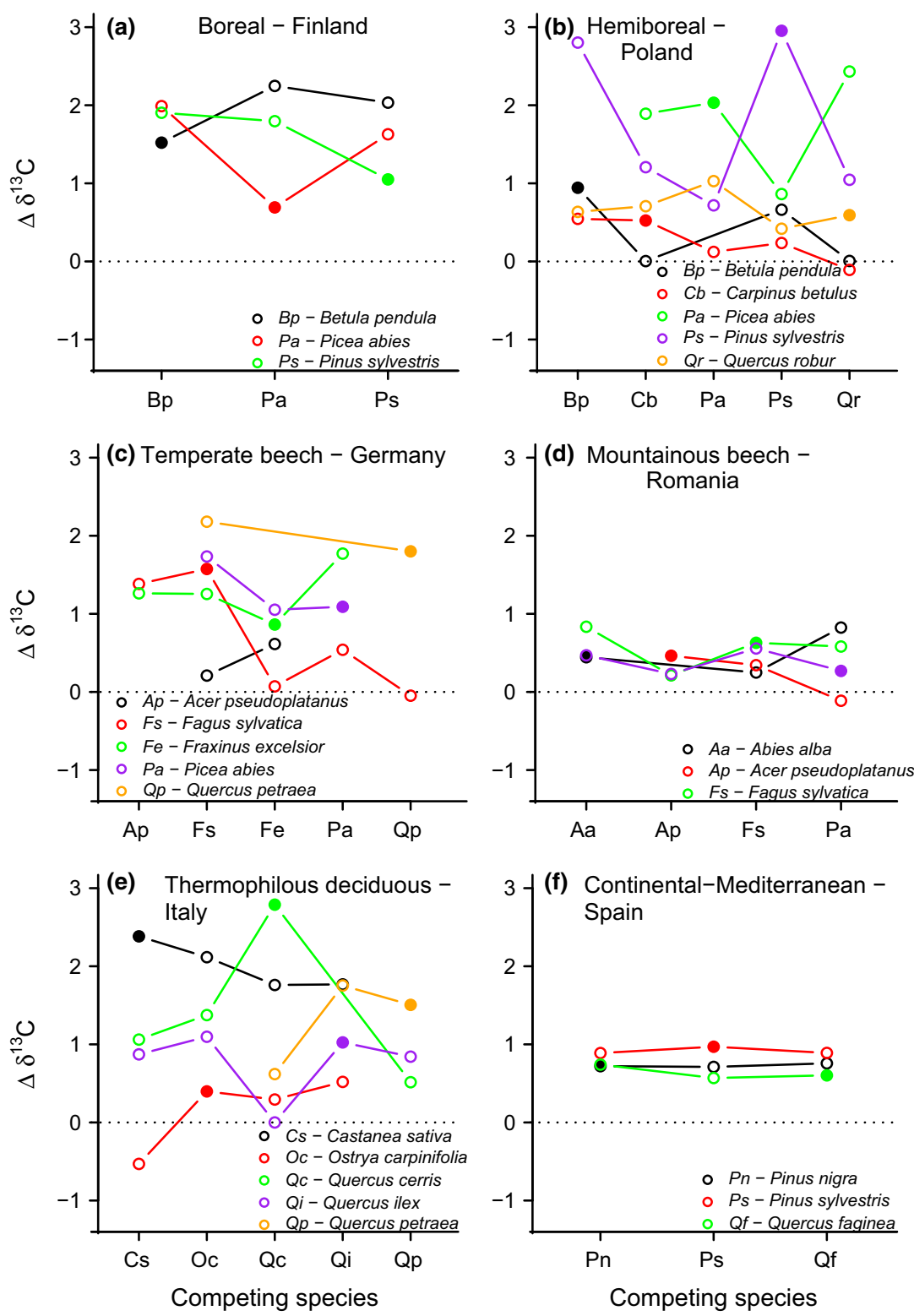

One of the most general findings was that there is no common relationship between diversity and $\Delta \delta^{13} \mathrm{C}$ and that the majority of species were not most water-stressed in their monocultures. This reduced the probability of negative correlations between diversity and drought stress $\left(\Delta \delta^{13} \mathrm{C}\right)$ within a given region because the response in mixtures, where there was a positive effect, was offset by the response in other mixtures where there was a negative effect. The two cases where water stress decreased with increasing diversity (i.e. F. sylvatica in Germany and C. sativa in Italy) were also examples of species-region combinations for which a given species was more stressed in monoculture than all two-species mixtures. It is also important to note that even within a given region there was no single species that was consistently more stressful to all others in that region.

With regard to management implications, while there were few significant relationships between $\Delta \delta^{13} \mathrm{C}$ and diversity, there were many two-species mixtures where both species were less water-stressed in mixture than in monoculture (e.g. mixtures of C. betulus or P. abies with $P$. sylvestris in Poland; $Q$. petraea or $C$. sativa with Q. cerris in Italy; Fig. 2). Thus, for most species, drought stress changed with neighbour identity rather than with diversity. There are no data from this study to provide a process-based explanation for why these combinations worked for each species within the mixture, and it is likely that a combination of processes was responsible, some of which improved water availability and others that may have simultaneously had the opposite effect (Forrester \& Bauhus 2016). For example, a conifer such as $P$. abies might reduce water availability by having higher interception rates than neighbouring broad-leaved species, such as $F$. sylvatica, but $P$. abies might also increase water availability by having a lower transpiration rate than $F$. sylvatica (Schume, Jost \& Hager 2004). 


\section{SITE AND REGION EFFECTS}

The design of this study allows an analysis of the relationship between diversity and species response to drought across major forest types in Europe and an indication of the generality of such relationships. Our results show that a given species combination can respond differently in different regions. For example, in Germany, F. sylvatica was less stressed in mixtures with all other species examined in that region, which is the same result that was found in another study in the same region (Metz et al. 2016). However, this was not the case in Romania, where $F$. sylvatica was more stressed in mixture with A. alba than in monocultures. Also, in Romania F. sylvatica was least waterstressed with Acer pseudoplatanus, which was actually the most stressful species towards F. sylvatica in Germany. Spatial changes in the interactions between a given combination of species in terms of growth have been found in many forests (Forrester 2014). This shows the risk of using data from a small part of a species distribution to generalize about a given species combination (Forrester 2014). For example, the mixing effect on growth of $P$. sylvestris and F. sylvatica was found to decrease from $78 \%$ at a single site in Germany, to $17 \%$ when averaged across seven sites in Germany and Poland, to $9 \%$ when averaged for 32 sites spread across a large proportion of the natural distribution of this species combination in Europe (Forrester \& Pretzsch 2015). Furthermore, different provenances of a given species can vary in their hydraulic architecture (Poyatos et al. 2007) or other water-related traits (Ponton et al. 2002) and thus in their response to droughts (Taeger et al. 2013), thereby influencing the way a given species interacts with others.

\section{STAND DENSITY}

With few exceptions, $\Delta \delta^{13} \mathrm{C}$ was not correlated with stand density (basal area or LAI) for any species in any of the six regions. As shown in previous studies at these sites, density was also only weakly correlated with tree species richness in each region (Jucker, Bouriaud \& Coomes 2015). The weak or absent correlation between stand density (basal area or LAI) and species-level $\Delta \delta^{13} \mathrm{C}$ may be due to unmeasured variables, such as differences in the hydraulic architecture of a given species in different plots. For example, a stand that was thinned several decades ago (via management or a natural disturbance) may now have a similar community basal area and LAI to stands that were less intensively thinned, but the trees of a given species within that stand could now have larger mean tree leaf areas and hence different hydraulic architectures. While the forests used in this study have not been recently managed, they are mature forests and all previous management during the first decades of stand development will have influenced the current stand structures and hydraulic architectures, which can influence the response of trees to droughts (McDowell et al. 2006; Sohn et al.
2013). Confounding effects of stand structure or hydraulic architecture may have caused the variable (and usually absent) effects of stand density on $\Delta \delta^{13} \mathrm{C}$. It should also be noted that while there were not enough data to test for interactions between diversity and stand density, this may be important to examine in future studies.

\section{MANAGEMENT CONSIDERATIONS AND CONCLUSIONS}

Diversity was often a poor predictor of the water stress response of individual species and all significant relationships at the community level were mirrored by the response of only one species within the community. This indicates that information about only a single species within a mixture provides very little information about the potential mixing effect on that community or all other species within the community. However, while species diversity does not appear to be a good predictor of community- or species-level water stress response, species identity is clearly important and there were many two-species mixtures in which both species were less waterstressed compared with their monocultures. It is also important to note that there were also two-species mixtures where one or both species were more water-stressed than in their monocultures (e.g. all mixtures in Finland). Therefore, while mixed-species forests may sometimes result in reduced water stress, this will certainly not always be the case. Furthermore, the mixing effect on water stress also varied between regions, and a species that benefited from mixing in one region (e.g. F. sylvatica with $P$. abies in Germany) did not always benefit, even when mixed with the same species, in another region (e.g. in Romania). These mixing effects are likely to result in several simultaneously occurring water-related interactions, some of which may have positive effects and others negative effects (Forrester \& Bauhus 2016). Further investigation of these processes and how they can be influenced by species interactions and forest management will be necessary to improve the process-based understanding of these dynamics. This will be required in order to more confidently predict which combinations of species, sites, climatic conditions, stand ages and stand structures will be most beneficial for reducing water stress of forests.

\section{Acknowledgements}

We are especially grateful to Bogdan Jaroszewicz, Filippo Bussotti, Timo Domish, Olivier Bouriaud, Helge Bruelheide, Leena Finer, Fernando Valladares and all the site technicians for establishing the study stands and for their logistical help. We thank Daniel Avăcăriței, Iulian Dănilă, Gabriel Duduman and Ionuț Bărnoaiea for their help with the wood core sampling. We thank the technical Isotope Platform of INRA Nancy and the Isotope Facility of UC Davis for the carbon isotope analyses. Part of the research leading to these results received funding from the European Union Seventh Framework Programme (FP7/2007-2013) under grant agreement no. 265171. We thank Michael Scherer-Lorenzen for his contribution to the success of the FunDivEUROPE project. D.I.F. was funded by a Heisenberg Fellowship (FO 791/4-1) from the German Research Foundation (Deutsche Forschungsgemeinschaft, DFG). A.G. acknowledges support from the Swiss National Science Foundation 
(31003A 159866/1). This research was conducted within the framework of the Laboratory of Excellence ARBRE ('Recherches Avancées sur la Biologie de l'Arbre et les Ecosystémes Forestiers'; ANR-12-LABXARBRE-01) supported by the French National Research Agency.

\section{Data accessibility}

FunDivEUROPE online data portal (http://fundiv.befdata.biow.uni-leip zig.de/)

Wood d13C (all sites): http://fundiv.befdata.biow.uni-leipzig.de/data sets $/ 334$

LAI Germany: http://fundiv.befdata.biow.uni-leipzig.de/datasets/222

LAI Italy: http://fundiv.befdata.biow.uni-leipzig.de/datasets/221

LAI Poland: http://fundiv.befdata.biow.uni-leipzig.de/datasets/224

LAI Romania: http://fundiv.befdata.biow.uni-leipzig.de/datasets/225

LAI Spain: http://fundiv.befdata.biow.uni-leipzig.de/datasets/226 150

Soil C/N (all sites): http://fundiv.befdata.biow.uni-leipzig.de/datasets/

Plot descriptors \& basal area Finland: http://fundiv.befdata.biow.unileipzig.de/datasets 67

Plot descriptors \& basal area Germany: http://fundiv.befdata.biow.unileipzig.de/datasets/82

Plot descriptors \& basal area Italy: http://fundiv.befdata.biow.uni-leip zig.de/datasets/ 68

Plot descriptors \& basal area Poland: http://fundiv.befdata.biow.unileipzig.de/datasets/ 69

Plot descriptors \& basal area Romania: http://fundiv.befdata.biow.unileipzig.de/datasets $/ 66$

Plot descriptors \& basal area Spain: http://fundiv.befdata.biow.uni-leip zig.de/datasets $/ 70$

\section{References}

Allen, C.D., Macalady, A.K., Chenchouni, H., Bachelet, D., McDowell, N., Vennetier, M. et al. (2010) A global overview of drought and heatinduced tree mortality reveals emerging climate change risks for forests. Forest Ecology and Management, 259, 660-684.

Baeten, L., Verheyen, K., Wirth, C., Bruelheide, H., Bussotti, F., Finér, L. et al. (2013) A novel comparative research platform designed to determine the functional significance of tree species diversity in European forests. Perspectives in Plant Ecology, Evolution and Systematics, 15, 281-291.

Bolker, B.M., Brooks, M.E., Clark, C.J., Geange, S.W., Poulsen, J.R., Stevens, M.H.H. \& White, J.-S.S. (2009) Generalized linear mixed models: a practical guide for ecology and evolution. Trends in Ecology \& Evolution, 24, 127-135.

Brendel, O., Pot, D., Plomion, C., Rozenberg, P. \& Guehl, J. (2002) Genetic parameters and QTL analysis of $\delta^{13} \mathrm{C}$ and ring width in maritime pine. Plant, Cell and Environment, 25, 945-953.

Cescatti, A. \& Piutti, E. (1998) Silvicultural alternatives, competition regime and sensitivity to climate in a European beech forest. Forest Ecology and Management, 102, 213-223.

Clarke, P. \& Wheaton, B. (2007) Addressing data sparseness in contextual population research: using cluster analysis to create synthetic neighborhoods. Sociological Methods \& Research, 35, 311-351.

Dupouey, J.L., Leavitt, S., Choisnel, E. \& Jourdain, S. (1993) Modelling carbon isotope fractionation in tree rings based on effective evapotranspiration and soil water status. Plant, Cell and Environment, 16, 939947

Farquhar, G.D., Ehleringer, J.R. \& Hubick, K.T. (1989) Carbon isotope discrimination and photosynthesis. Annual Review of Plant Physiology and Plant Molecular Biology, 40, 503-537.

Ferrio, J.P., Voltas, J. \& Araus, J.L. (2003) Use of carbon isotope composition in monitoring environmental changes. Management of Environmental Quality: An International Journal, 14, 82-98.

Ferrio, J.P., Florit, A., Vega, A., Serrano, L. \& Voltas, J. (2003) $\Delta^{13} \mathrm{C}$ and tree-ring width reflect different drought responses in Quercus ilex and Pinus halepensis. Oecologia, 137, 512-518.
Forrester, D.I. (2014) The spatial and temporal dynamics of species interactions in mixed-species forests: from pattern to process. Forest Ecology and Management, 312, 282-292.

Forrester, D.I. (2015) Transpiration and water-use efficiency in mixed-species forests versus monocultures: effects of tree size, stand density and season. Tree Physiology, 35, 289-304.

Forrester, D.I. \& Bauhus, J. (2016) A review of processes behind diversity - productivity relationships in forests. Current Forestry Reports, 2, 4561.

Forrester, D.I. \& Pretzsch, H. (2015) Tamm review: on the strength of evidence when comparing ecosystem functions of mixtures with monocultures. Forest Ecology and Management, 356, 41-53.

Forrester, D.I., Theiveyanathan, S., Collopy, J.J. \& Marcar, N.E. (2010) Enhanced water use efficiency in a mixed Eucalyptus globulus and Acacia mearnsii plantation. Forest Ecology and Management, 259, 17611770

Gebauer, T., Horna, V. \& Leuschner, C. (2012) Canopy transpiration of pure and mixed forest stands with variable abundance of European beech. Journal of Hydrology, 442-443, 2-14.

Grossiord, C., Granier, A., Gessler, A., Pollastrini, M. \& Bonal, D. (2013) The influence of tree species mixture on ecosystem-level carbon accumulation and water use in a mixed boreal plantation. Forest Ecology and Management, 298, 82-92.

Grossiord, C., Granier, A., Gessler, A., Jucker, T. \& Bonal, D. (2014a) Does drought influence the relationship between biodiversity and ecosystem functioning in boreal forests? Ecosystems, 17, 394-404.

Grossiord, C., Granier, A., Ratcliffe, S., Bouriaud, O., Bruelheide, H., Chećko, E. et al. (2014b) Tree diversity does not always improve resistance of forest ecosystems to drought. Proceedings of the National Academy of Sciences, 111, 14812-14815.

Jucker, T., Bouriaud, O. \& Coomes, D.A. (2015) Crown plasticity enables trees to optimize canopy packing in mixed-species forests. Functional Ecology, 29, 1078-1086.

Kunert, N., Schwendenmann, L., Potvin, C. \& Hölscher, D. (2012) Tree diversity enhances tree transpiration in a Panamanian forest plantation. Journal of Applied Ecology, 49, 135-144.

Laurent, M., Antoine, N. \& Joel, G. (2003) Effects of different thinning intensities on drought response in Norway spruce (Picea abies (L.) Karst.). Forest Ecology and Management, 183, 47-60.

Law, B.E., Falge, E., Guc, L., Baldocchi, D.D., Bakwind, P., Berbigier, P. et al. (2002) Environmental controls over carbon dioxide and water vapor exchange of terrestrial vegetation. Agricultural and Forest Meteorology, 113, 97-120.

Lebourgeois, F., Gomez, N., Pinto, P. \& Mérian, P. (2013) Mixed stands reduce Abies alba tree-ring sensitivity to summer drought in the Vosges mountains, western Europe. Forest Ecology and Management, 303, 6171.

Loader, N.J., Robertson, I. \& McCarroll, D. (2003) Comparison of stable carbon isotope ratios in the whole wood, cellulose and lignin of oak tree-rings. Palaeogeography, Palaeoclimatology, Palaeoecology, 196, 395-407.

van Mantgem, P.J. \& Stephenson, N.L. (2007) Apparent climatically induced increase of tree mortality rates in a temperate forest. Ecology Letters, 10, 909-916.

Martín-Benito, D., Río, M.D., Heinrich, I., Helle, G. \& Cañellas, I. (2010) Response of climate-growth relationships and water use efficiency to thinning in a Pinus nigra afforestation. Forest Ecology and Management, 259, 967-975.

McDowell, N.G., Adams, H.D., Bailey, J.D., Hess, M. \& Kolb, T.E (2006) Homeostatic maintenance of ponderosa pine gas exchange in response to stand density changes. Ecological Applications, 16, 1164 1182

Messier, C., Puettmann, K.J. \& Coates, K.D. (2013) Managing Forests as Complex Adaptive Systems: Building Resilience to the Challenge of Global Change, pp. 353. Routledge Chapman \& Hall, New York.

Metz, J., Annighöfer, P., Schall, P., Zimmermann, J., Kahl, T., Schulze, E.-D. \& Ammer, C. (2016) Site adapted admixed tree species reduce drought susceptibility of mature European beech. Global Change Biology, 22, 903-920.

Mölder, I. \& Leuschner, C. (2014) European beech grows better and is less drought sensitive in mixed than in pure stands: tree neighbourhood effects on radial increment. Trees, 28, 777-792.

Moore, G.W., Bond, B.J. \& Jones, J.A. (2011) A comparison of annual transpiration and productivity in monoculture and mixed-species 
Douglas-fir and red alder stands. Forest Ecology and Management, 262. $2263-2270$.

Offermann, C., Ferrio, J.P., Holst, J., Grote, R., Siegwolf, R., Kayler, Z. $\&$ Gessler, A. (2011) The long way down - are carbon and oxygen isotope signals in the tree ring uncoupled from canopy physiological processes? Tree Physiology, 31, 1088-1102.

Paquette, A. \& Messier, C. (2011) The effect of biodiversity on tree productivity: from temperate to boreal forests. Global Ecology and Biogeography, 20, 170-180.

Peñuelas, J., Hunt, J.M., Ogaya, R. \& Jump, A.S. (2008) Twentieth century changes of tree-ring $\delta^{13} \mathrm{C}$ at the southern range-edge of Fagus sylvatica: increasing water-use efficiency does not avoid the growth decline induced by warming at low altitudes. Global Change Biology, 14, 10761088

Ponton, S., Dupouey, J.L., Bréda, N. \& Dreyer, E. (2002) Comparison of water-use efficiency of seedlings from two sympatric oak species: genotype X environment interactions. Tree Physiology, 22, 413-422.

Poyatos, R., Martínez-Vilalta, J., Cermák, J., Ceulemans, R., Granier, A., Irvine, J. et al. (2007) Plasticity in hydraulic architecture of Scots pine across Eurasia. Oecologia, 153, 245-259.

Pretzsch, H., Schütze, G. \& Uhl, E. (2013) Resistance of European tree species to drought stress in mixed versus pure forests: evidence of stress release by inter-specific facilitation. Plant Biology, 15, 483-495.

R Core Team (2015) R: A Language and Environment for Statistical Computing. R Foundation for Statistical Computing, Vienna, Austria. URL http://www.R-project.org/

Saurer, M., Siegenthaler, U. \& Schweingruber, F. (1995) The climate carbon isotope relationship in tree rings and the significance of site conditions. Tellus, 47B, 320-330.

Schume, H., Jost, G. \& Hager, H. (2004) Soil water depletion and recharge patterns in mixed and pure forest stands of European beech and Norway spruce. Journal of Hydrology, 289, 258-274.

Shannon, C.E. (1948) A mathematical theory of communication. The Bell System Technical Journal, 27, 379-423, 623-656.

Sohn, J.A., Gebhardt, T., Ammer, C., Bauhus, J., Häberle, K.-H., Matyssek, R. \& Grams, T.E.E. (2013) Mitigation of drought by thinning: short-term and long-term effects on growth and physiological performance of Norway spruce (Picea abies). Forest Ecology and Management, 308, 188-197.

Taeger, S., Zang, C., Liesebach, M., Schneck, V. \& Menzel, A. (2013) Impact of climate and drought events on the growth of Scots pine (Pinus sylvestris L.) provenances. Forest Ecology and Management, 307, $30-42$

Vilà, M., Carrillo-Gavilán, A., Vayreda, J., Bugmann, H., Fridman, J., Grodzki, W. et al. (2013) Disentangling biodiversity and climatic determinants of wood production. PLoS One, 8, e53530.
Volkmann, T.H.M., Haberer, K., Gessler, A. \& Weiler, M. (2016) Highresolution isotope measurements resolve rapid ecohydrological dynamics at the soil-plant interface. New Phytologist, 210, 839-849.

Warren, C.R., McGrath, J.F. \& Adams, M.A. (2001) Water availability and carbon isotope discrimination in conifers. Oecologia, 127, 476-486.

Zhang, Y., Chen, H.Y.H. \& Reich, P.B. (2012) Forest productivity increases with evenness, species richness and trait variation: a global meta-analysis. Journal of Ecology, 100, 742-749.

Received 8 February 2016; accepted 5 July 2016

Handling Editor: John Finn

\section{Supporting Information}

Additional Supporting Information may be found in the online version of this article.

Appendix S1. Quantification of soil water availability, leaf area index and soil $\mathrm{C} / \mathrm{N}$.

Fig. S1. Relationship between $\Delta \delta^{13} \mathrm{C}$ and tree species richness.

Fig. S2. Relationship between $\Delta \delta^{13} \mathrm{C}$ and stand basal area.

Fig. S3. Relationship between $\Delta \delta^{13} \mathrm{C}$ and leaf area index.

Fig. S4. Relationship between $\Delta \delta^{13} \mathrm{C}$ and soil $\mathrm{C}$ to $\mathrm{N}$ ratio.

Table S1. Statistics for relationship between $\Delta \delta^{13} \mathrm{C}$ and tree species diversity.

Table S2. Statistics for relationship between $\Delta \delta^{13} \mathrm{C}$ and tree species richness.

Table S3. Relationship between $\Delta \delta^{13} \mathrm{C}$ and stand basal area.

Table S4. Relationship between $\Delta \delta^{13} \mathrm{C}$ and leaf area index.

Table S5. Relationship between $\Delta \delta^{13} \mathrm{C}$ and soil $\mathrm{C}$ to $\mathrm{N}$ ratio. 
Drought responses by individual tree species are not often correlated with tree species diversity in European forests

David Forrester, Damien Bonal, Seid Dawud, Arthur Gessler, André Granier, Martina Pollastrini, Charlotte Grossiord

\section{Supporting Information}

Appendix S1. Quantification of soil water availability, leaf area index and soil C/N 2

Fig. S1. Relationship between $\Delta \delta^{13} \mathrm{C}$ and tree species richness $\quad 5$

Fig. S2. Relationship between $\Delta \delta^{13} \mathrm{C}$ and stand basal area $\quad 6$

Fig. S3. Relationship between $\Delta \delta^{13} \mathrm{C}$ and leaf area index $\quad 7$

Fig. S4. Relationship between $\Delta \delta^{13} \mathrm{C}$ and soil $\mathrm{C}$ to $\mathrm{N}$ ratio 8

Table S1. Statistics for relationship between $\Delta \delta^{13} \mathrm{C}$ and tree species diversity $\quad 9$

Table S2. Statistics for relationship between $\Delta \delta^{13} \mathrm{C}$ and tree species richness $\quad 10$

Table S3. Statistics for relationship between $\Delta \delta^{13} \mathrm{C}$ and stand basal area $\quad 11$

Table S4. Statistics for relationship between $\Delta \delta^{13} \mathrm{C}$ and leaf area index $\quad 12$

Table S5. Statistics for relationship between $\Delta \delta^{13} \mathrm{C}$ and soil C to N ratio 13 
Drought responses by individual tree species are not often correlated with tree species diversity in European forests

David Forrester, Damien Bonal, Seid Dawud, Arthur Gessler, André Granier, Martina Pollastrini, Charlotte Grossiord

\section{Appendix 1. Quantification of soil water availability, leaf area index and soil C/N}

\section{Soil water availability}

The growing seasons with non-limiting soil water conditions and those with severe soil drought were selected using a water balance model, BILJOU (Granier et al. 1999), to estimate the daily relative extractable water (REW, unitless) for each region between 1997 and 2010. The year of 1997 was the longest backwards projection used because the stand characteristics measured in 2012-2013 will become less representative as the length of the backwards projection is increased; an arbitrary maximum of 15 years was considered to be reasonable in these mature forests. REW is the ratio between available soil water and the maximum extractable water (water holding capacity) and varies between one (field capacity) and zero (permanent wilting point). A REW $>0.4$ indicates non-limiting soil water conditions for transpiration such that stomatal conductance will depend more on vapour pressure deficit and irradiance (Granier et al. 1999). A REW <0.4 indicates a soil water shortage that can induce a reduction in stomatal conductance and thus in leaf gas exchange, causing many tree species to cease radial growth (Granier et al. 1999).

The BILJOU model has a daily time step and the required input variables are daily precipitation, global radiation, air temperature, humidity and wind speed, as well as soil water holding capacity and leaf area index (LAI). Meteorological data for each of the six regions were obtained from the CGMS database of interpolated meteorological data (AGRI4CAST, http://mars.jrc.ec.europa.eu/mars). For each year in each region, the annual water stress was quantified using an index (unitless) (Granier et al. 1999) that cumulates the difference between daily REW and 0.4 when REW is $<0.4$ according to Equation 2 . 
Drought responses by individual tree species are not often correlated with tree species diversity in European forests

David Forrester, Damien Bonal, Seid Dawud, Arthur Gessler, André Granier, Martina Pollastrini, Charlotte Grossiord

Water Stress Index $=\frac{\sum_{j}\left(0.4-R E W_{j}\right)}{0.4}$,

where $j$ corresponds to each day when $\mathrm{REW}<0.4$.

For each region, the dry year used for $\delta^{13} \mathrm{C}_{\mathrm{dry}}$ was randomly selected from the three driest years between 1997 and 2010. The wet year used for $\delta^{13} \mathrm{C}_{\text {wet }}$ was randomly selected from the years with a water stress index of $<6.0$ (arbitrary threshold). More detail is provided in Grossiord et al. (2014a); Grossiord et al. (2014b).

\section{Leaf area index and soil $\mathrm{C} / \mathrm{N}$}

The LAI was measured at five locations within each plot during the summers of 2012 and 2013 using a LAI-2000 Plant Canopy Analyzer (LI-COR Inc., Lincoln, Nebraska). Soil C/N ratio was measured from nine forest floor (O-horizon) samples and mineral soil cores from each plot. The soil cores were divided into depth classes $(0-10 \mathrm{~cm}, 10-20 \mathrm{~cm}$, and depending on soil depth and stoniness, 20-30 and 30-40 cm). All nine forest floor and mineral soil samples per plot were bulked into a single sample per plot. The O-horizon and mineral soil samples were dried at $55^{\circ} \mathrm{C}$ to constant weight. The O-horizon samples were ground with a Heavy-duty Retsch Model SM 2000 cutting mill before subsamples were ground into finer particles using a ball mill. Mineral soil samples were sieved (2-mm-diameter) and then ground using a Planetary PM 400 Retsch ball mill. Subsamples from the forest floor and mineral soils were taken and dried at $105^{\circ} \mathrm{C}$ to determine the moisture content. Thus, the $\mathrm{C}$ concentrations are reported at dry weight basis. The soil $\mathrm{C}$ and total $\mathrm{N}$ concentrations were 
Drought responses by individual tree species are not often correlated with tree species diversity in European forests

David Forrester, Damien Bonal, Seid Dawud, Arthur Gessler, André Granier, Martina Pollastrini, Charlotte Grossiord

analysed using an elemental analyzer (Thermo Scientific FLASH 2000 organic elemental analyzer) following the dry combustion method (Matejovic 1993). A mean C/N ratio was calculated for each plot.

\section{References}

Granier, A., Bréda, N., Biron, P. \& Villette, S. (1999) A lumped water balance model to evaluate duration and intensity of drought constraints in forest stands. Ecological Modelling, 116, 269-283.

Grossiord, C., Granier, A., Gessler, A., Jucker, T. \& Bonal, D. (2014a) Does drought influence the relationship between biodiversity and ecosystem functioning in boreal forests? Ecosystems, 17, 394-404.

Grossiord, C., Granier, A., Ratcliffe, S., Bouriaud, O., Bruelheide, H., Chećko, E., Forrester, D.I., Dawud, S.M., Finér, L., Pollastrini, M., Scherer-Lorenzen, M., Valladares, F., Bonal, D. \& Gessler, A. (2014b) Tree diversity does not always improve resistance of forest ecosystems to drought. Proceedings of the National Academy of Sciences, 111, 14812-14815.

Matejovic, I. (1993) Determination of carbon, hydrogen, and nitrogen in soils by automated elemental analysis (dry combustion method). Communications in Soil Science and Plant Analysis, 24, 2213-2222. 
Drought responses by individual tree species are not often correlated with tree species diversity in European forests

David Forrester, Damien Bonal, Seid Dawud, Arthur Gessler, André Granier, Martina Pollastrini, Charlotte Grossiord
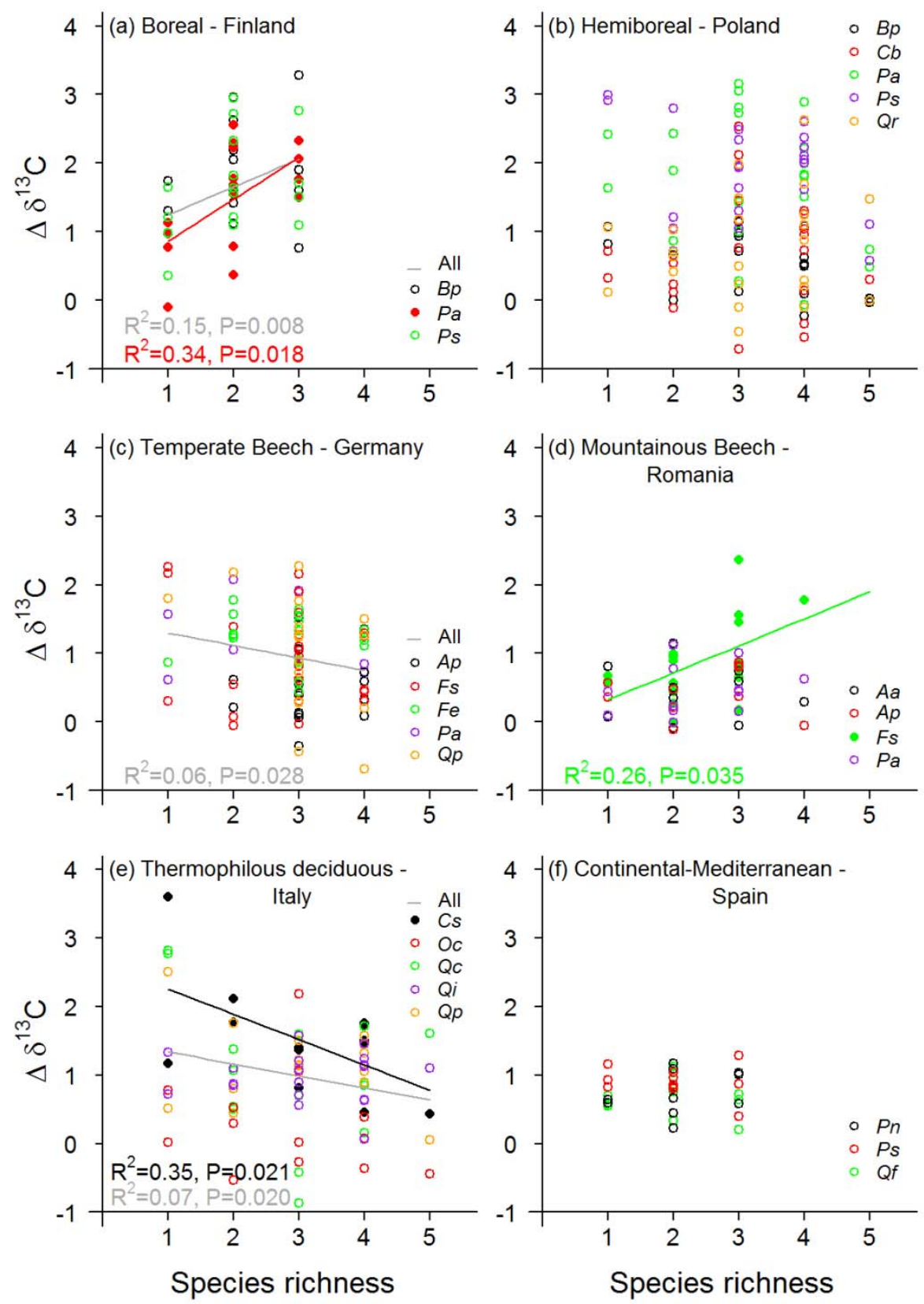

Figure S1. Increase in the species-specific carbon isotope composition in a dry year,

compared with a wet year $\left(\Delta \delta^{13} \mathrm{C}, \%\right)$, in relation to tree species richness, for each region.

Richness is quantified as the number of species in the stand. Species codes are the same as in

Table 1. The fitted lines show the statistically significant relationships $(\mathrm{P}<0.05)$. The grey

lines are fitted for all species combined. The corresponding $\mathrm{R}^{2}$ and $\mathrm{P}$ values are provided using the same colour as the lines. 
Drought responses by individual tree species are not often correlated with tree species diversity in European forests

David Forrester, Damien Bonal, Seid Dawud, Arthur Gessler, André Granier, Martina Pollastrini, Charlotte Grossiord
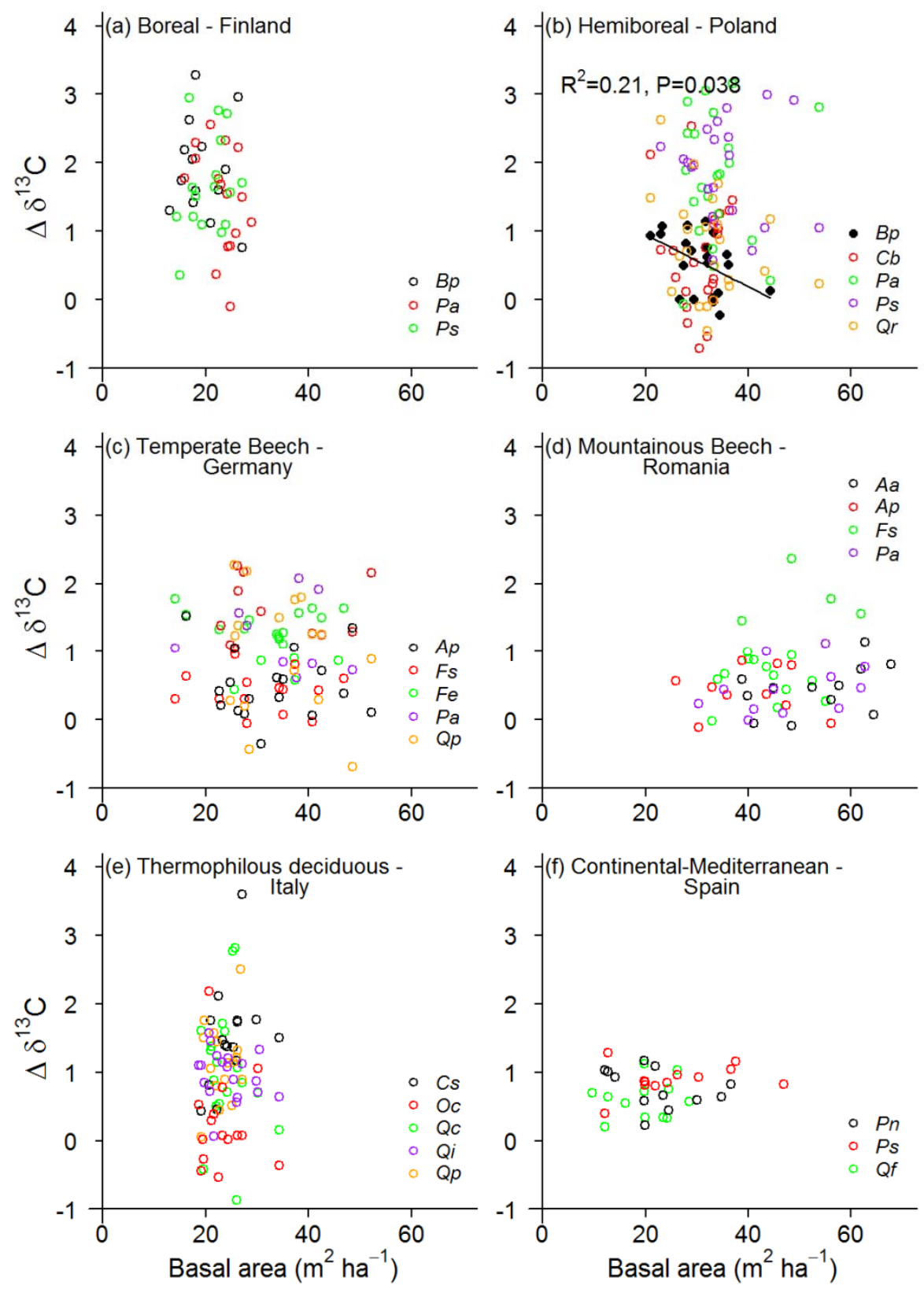

Figure S2. Increase in the species-specific carbon isotope composition in a dry year, compared with a wet year $\left(\Delta \delta^{13} \mathrm{C}, \%\right)$, in relation to total stand basal area, for each region. Species codes are the same as in Table 1 . The fitted line shows the only statistically significant relationship $(\mathrm{P}<0.05)$. 
Drought responses by individual tree species are not often correlated with tree species diversity in European forests

David Forrester, Damien Bonal, Seid Dawud, Arthur Gessler, André Granier, Martina Pollastrini, Charlotte Grossiord
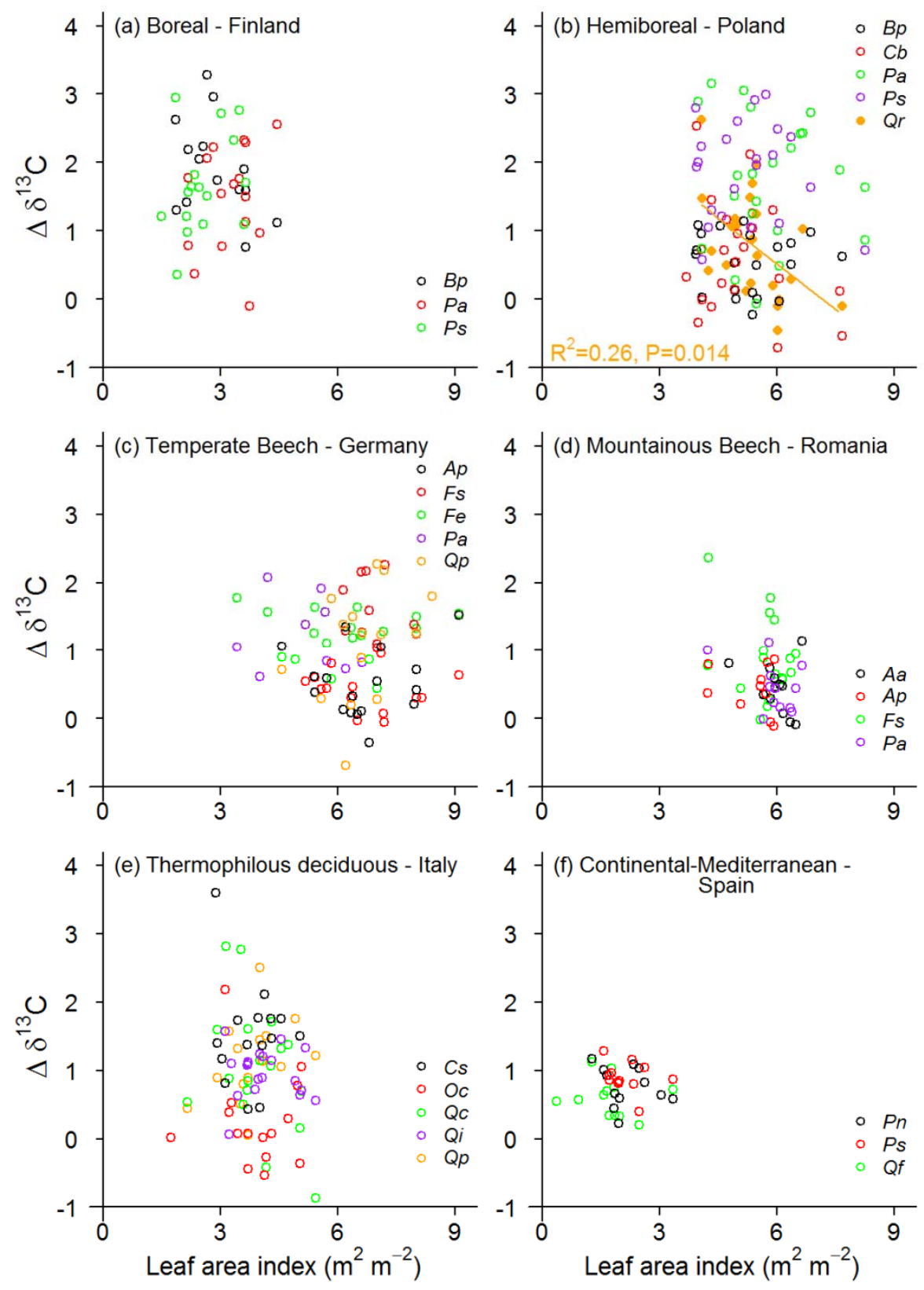

Figure S3. Increase in the species-specific carbon isotope composition in a dry year, compared with a wet year $\left(\Delta \delta^{13} \mathrm{C}, \%\right)$, in relation to leaf area index, for each region. Species codes are the same as in Table 1 . The fitted line shows the only statistically significant relationship $(\mathrm{P}<0.05)$. 
Drought responses by individual tree species are not often correlated with tree species diversity in European forests

David Forrester, Damien Bonal, Seid Dawud, Arthur Gessler, André Granier, Martina Pollastrini, Charlotte Grossiord
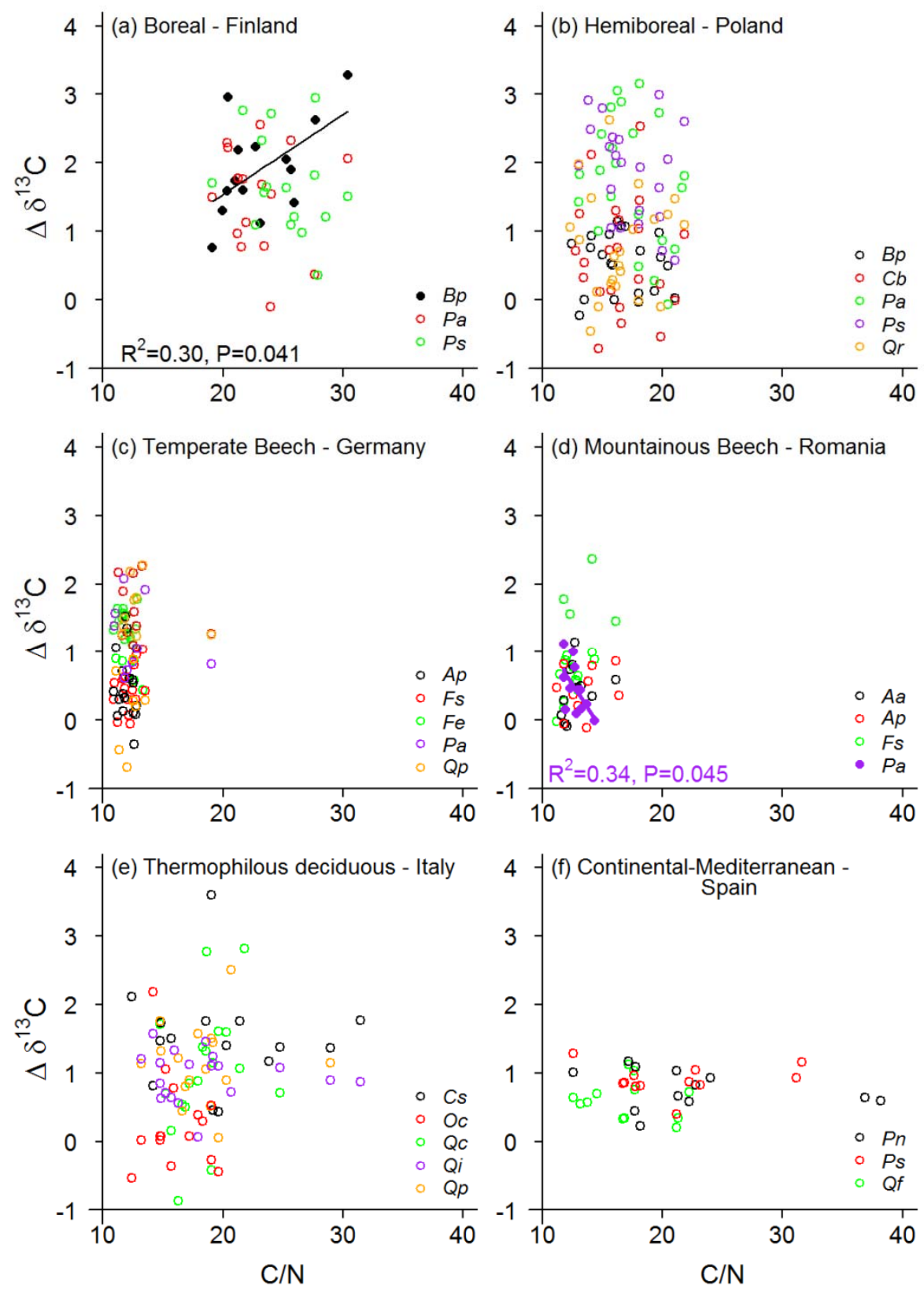

Figure S4. Increase in the species-specific carbon isotope composition in a dry year, compared with a wet year $\left(\Delta \delta^{13} \mathrm{C}, \%\right)$, in relation to soil $\mathrm{C}$ to soil $\mathrm{N}$ ratio $(\mathrm{C} / \mathrm{N})$, for each region. Species codes are the same as in Table 1 . The fitted lines show the only statistically significant relationship $(\mathrm{P}<0.05)$. 
Drought responses by individual tree species are not often correlated with tree species diversity in European forests

David Forrester, Damien Bonal, Seid Dawud, Arthur Gessler, André Granier, Martina Pollastrini, Charlotte Grossiord

Table S1. Summary statistics for the relationships between $\Delta \delta^{13} \mathrm{C}(\% \mathrm{o})$ and tree species diversity (i.e. Shannon's index) for each species and for all data combined. When the relationships were significant $(\mathrm{P}<0.05)$ the intercept and slope parameters are also provided with standard errors of the parameters estimates in parentheses.

\begin{tabular}{|c|c|c|c|c|c|c|}
\hline Region and species & $\mathrm{n}$ & F-value & P-value & $\mathrm{R}^{2}$ & Intercept (se) & Slope (se) \\
\hline \multicolumn{7}{|l|}{ Boreal - Finland } \\
\hline Betula pendula & 14 & 0.041 & 0.843 & & & \\
\hline Picea abies & 16 & 5.938 & 0.029 & 0.30 & $0.77(0.34)$ & $0.88(0.36)$ \\
\hline Pinus sylvestris & 16 & 4.313 & 0.057 & & & \\
\hline All combined & 46 & 7.997 & 0.007 & 0.15 & $1.11(0.22)$ & $0.65(0.23)$ \\
\hline \multicolumn{7}{|l|}{ Hemiboreal - Poland } \\
\hline Betula pendula & 21 & 1.481 & 0.239 & & & \\
\hline Carpinus betulus & 22 & 0.037 & 0.849 & & & \\
\hline Picea abies & 22 & 1.282 & 0.271 & & & \\
\hline Pinus sylvestris & 22 & 1.920 & 0.181 & & & \\
\hline Quercus robur & 23 & 0.209 & 0.652 & & & \\
\hline All combined & 110 & 1.658 & 0.201 & & & \\
\hline \multicolumn{7}{|l|}{ Temperate Beech - Germany } \\
\hline Acer pseudoplatanus & 18 & 0.287 & 0.599 & & & \\
\hline Fagus sy/vatica & 25 & 7.759 & 0.011 & 0.25 & $1.88(0.36)$ & $-0.72(0.26)$ \\
\hline Fraxinus excelsior & 19 & 0.527 & 0.478 & & & \\
\hline Picea abies & 9 & 0.198 & 0.670 & & & \\
\hline Quercus petraea & 16 & 1.116 & 0.309 & & & \\
\hline All combined & 87 & 6.571 & 0.012 & 0.07 & $1.56(0.25)$ & $-0.44(0.17)$ \\
\hline \multicolumn{7}{|l|}{ Mountainous Beech - Romania } \\
\hline Abies alba & 13 & 0.002 & 0.964 & & & \\
\hline Acer pseudoplatanus & 10 & 0.022 & 0.886 & & & \\
\hline Fagus sy/vatica & 17 & 3.481 & 0.082 & & & \\
\hline Picea abies & 12 & 1.166 & 0.306 & & & \\
\hline All combined & 52 & 2.508 & 0.120 & & & \\
\hline \multicolumn{7}{|l|}{ Thermophilous deciduous - Italy } \\
\hline Castanea sativa & 15 & 6.251 & 0.027 & 0.32 & $2.43(0.40)$ & $-0.66(0.27)$ \\
\hline Ostrya carpinifolia & 15 & 1.011 & 0.333 & & & \\
\hline Quercus cerris & 18 & 3.674 & 0.073 & & & \\
\hline Quercus ilex & 19 & 0.148 & 0.705 & & & \\
\hline Quercus petraea & 16 & 1.862 & 0.194 & & & \\
\hline All combined & 83 & 9.581 & 0.003 & 0.11 & $1.61(0.22)$ & $-0.44(0.14)$ \\
\hline \multicolumn{7}{|c|}{ Continental-Mediterranean - Spain } \\
\hline Pinus nigra & 12 & 0.072 & 0.794 & & & \\
\hline Pinus sylvestris & 12 & 0.384 & 0.549 & & & \\
\hline Quercus faginea & 12 & 0.161 & 0.697 & & & \\
\hline All combined & 36 & 0.097 & 0.757 & & & \\
\hline
\end{tabular}


Drought responses by individual tree species are not often correlated with tree species diversity in European forests

David Forrester, Damien Bonal, Seid Dawud, Arthur Gessler, André Granier, Martina Pollastrini, Charlotte Grossiord

Table S2. Summary statistics for the relationships between $\Delta \delta^{13} \mathrm{C}(\%)$ and tree species richness for each species and all data combined. When the relationships were significant $(\mathrm{P}<$ 0.05) the intercept and slope parameters are also provided with standard errors of the parameters estimates in parentheses.

\begin{tabular}{|c|c|c|c|c|c|c|}
\hline Region and species & $\mathrm{n}$ & $\mathrm{F}$ & $P$ & $\mathrm{R}^{2}$ & Intercept (se) & Slope (se) \\
\hline \multicolumn{7}{|l|}{ Boreal - Finland } \\
\hline Betula pendula & 14 & 0.149 & 0.706 & & & \\
\hline Picea abies & 16 & 7.257 & 0.017 & 0.34 & $0.26(0.48)$ & $0.61(0.23)$ \\
\hline Pinus sylvestris & 16 & 2.163 & 0.164 & & & \\
\hline All combined & 46 & 7.684 & 0.008 & 0.15 & $0.84(0.32)$ & $0.41(0.15)$ \\
\hline \multicolumn{7}{|l|}{ Hemiboreal - Poland } \\
\hline Betula pendula & 21 & 2.050 & 0.169 & & & \\
\hline Carpinus betulus & 22 & 0.005 & 0.947 & & & \\
\hline Picea abies & 22 & 1.760 & 0.20 & & & \\
\hline Pinus sylvestris & 22 & 1.796 & 0.195 & & & \\
\hline Quercus robur & 23 & 0.401 & 0.534 & & & \\
\hline All combined & 110 & 1.377 & 0.243 & & & \\
\hline \multicolumn{7}{|l|}{ Temperate Beech - Germany } \\
\hline Acer pseudoplatanus & 18 & 0.328 & 0.575 & & & \\
\hline Fagus sylvatica & 25 & 0.935 & 0.344 & & & \\
\hline Fraxinus excelsior & 19 & 0.000 & 0.991 & & & \\
\hline Picea abies & 9 & 0.440 & 0.529 & & & \\
\hline Quercus petraea & 16 & 3.467 & 0.084 & & & \\
\hline All combined & 87 & 4.970 & 0.028 & 0.06 & $1.48(0.25)$ & $-0.18(0.08)$ \\
\hline \multicolumn{7}{|l|}{ Mountainous Beech - Romania } \\
\hline Abies alba & 13 & 0.008 & 0.933 & & & \\
\hline Acer pseudoplatanus & 10 & 0.011 & 0.918 & & & \\
\hline Fagus sy/vatica & 17 & 5.364 & 0.035 & 0.26 & $-0.07(0.43)$ & $0.39(0.17)$ \\
\hline Picea abies & 12 & 0.770 & 0.401 & & & \\
\hline All combined & 52 & 3.183 & 0.080 & & & \\
\hline \multicolumn{7}{|l|}{ Thermophilous deciduous - Italy } \\
\hline Castanea sativa & 15 & 6.877 & 0.021 & 0.35 & $2.62(0.45)$ & $-0.37(0.14)$ \\
\hline Ostrya carpinifolia & 15 & 0.642 & 0.438 & & & \\
\hline Quercus cerris & 18 & 1.540 & 0.233 & & & \\
\hline Quercus ilex & 19 & 0.043 & 0.839 & & & \\
\hline Quercus petraea & 16 & 1.034 & 0.327 & & & \\
\hline All combined & 83 & 5.640 & 0.020 & 0.07 & $1.51(0.24)$ & $-0.18(0.07)$ \\
\hline \multicolumn{7}{|c|}{ Continental-Mediterranean - Spain } \\
\hline Pinus nigra & 12 & 0.397 & 0.543 & & & \\
\hline Pinus sylvestris & 12 & 0.407 & 0.538 & & & \\
\hline Quercus faginea & 12 & 0.122 & 0.734 & & & \\
\hline All combined & 36 & 0.014 & 0.908 & & & \\
\hline
\end{tabular}


Drought responses by individual tree species are not often correlated with tree species diversity in European forests

David Forrester, Damien Bonal, Seid Dawud, Arthur Gessler, André Granier, Martina Pollastrini, Charlotte Grossiord

Table S3. Summary statistics for the relationships between $\Delta \delta^{13} \mathrm{C}(\%)$ and basal area $\left(\mathrm{m}^{2} \mathrm{ha}^{-}\right.$ $\left.{ }^{1}\right)$ for each species and all data combined. When the relationships were significant $(\mathrm{P}<0.05)$ the intercept and slope parameters are also provided with standard errors of the parameters estimates in parentheses.

\begin{tabular}{|c|c|c|c|c|c|c|}
\hline Region and species & $\mathrm{n}$ & $\mathrm{F}$ & $\mathrm{P}$ & $\mathrm{R}^{2}$ & Intercept (se) & Slope (se) \\
\hline \multicolumn{7}{|l|}{ Boreal - Finland } \\
\hline Betula pendula & 14 & 0.068 & 0.799 & & & \\
\hline Picea abies & 16 & 2.387 & 0.145 & & & \\
\hline Pinus sylvestris & 16 & 1.322 & 0.270 & & & \\
\hline All combined & 46 & 0.830 & 0.367 & & & \\
\hline \multicolumn{7}{|l|}{ Hemiboreal - Poland } \\
\hline Betula pendula & 21 & 5.002 & 0.038 & 0.21 & $1.71(0.53)$ & $-0.04(0.02)$ \\
\hline Carpinus betulus & 22 & 0.007 & 0.933 & & & \\
\hline Picea abies & 22 & 0.051 & 0.824 & & & \\
\hline Pinus sylvestris & 22 & 0.128 & 0.724 & & & \\
\hline Quercus robur & 23 & 2.254 & 0.148 & & & \\
\hline All combined & 110 & 0.504 & 0.479 & & & \\
\hline \multicolumn{7}{|l|}{ Temperate Beech - Germany } \\
\hline Acer pseudoplatanus & 18 & 0.060 & 0.810 & & & \\
\hline Fagus sylvatica & 25 & 0.250 & 0.622 & & & \\
\hline Fraxinus excelsior & 19 & 0.265 & 0.613 & & & \\
\hline Picea abies & 9 & 0.047 & 0.835 & & & \\
\hline Quercus petraea & 16 & 0.747 & 0.402 & & & \\
\hline All combined & 87 & 0.124 & 0.725 & & & \\
\hline \multicolumn{7}{|l|}{ Mountainous Beech - Romania } \\
\hline Abies alba & 13 & 1.575 & 0.236 & & & \\
\hline Acer pseudoplatanus & 10 & 0.019 & 0.895 & & & \\
\hline Fagus sy/vatica & 17 & 2.271 & 0.153 & & & \\
\hline Picea abies & 12 & 1.674 & 0.225 & & & \\
\hline All combined & 52 & 2.054 & 0.158 & & & \\
\hline \multicolumn{7}{|l|}{ Thermophilous deciduous - Italy } \\
\hline Castanea sativa & 15 & 2.370 & 0.148 & & & \\
\hline Ostrya carpinifolia & 15 & 0.071 & 0.794 & & & \\
\hline Quercus cerris & 18 & 0.241 & 0.630 & & & \\
\hline Quercus ilex & 19 & 0.837 & 0.373 & & & \\
\hline Quercus petraea & 16 & 0.531 & 0.478 & & & \\
\hline All combined & 83 & 0.280 & 0.598 & & & \\
\hline \multicolumn{7}{|c|}{ Continental-Mediterranean - Spain } \\
\hline Pinus nigra & 12 & 1.299 & 0.281 & & & \\
\hline Pinus sylvestris & 12 & 0.682 & 0.428 & & & \\
\hline Quercus faginea & 12 & 0.285 & 0.605 & & & \\
\hline All combined & 36 & 0.609 & 0.441 & & & \\
\hline
\end{tabular}


Drought responses by individual tree species are not often correlated with tree species diversity in European forests

David Forrester, Damien Bonal, Seid Dawud, Arthur Gessler, André Granier, Martina Pollastrini, Charlotte Grossiord

Table S4. Summary statistics for the relationships between $\Delta \delta^{13} \mathrm{C}(\%)$ and leaf area index $\left(\mathrm{m}^{2} \mathrm{~m}^{-2}\right)$ for each species and all data combined. When the relationships were significant $(\mathrm{P}<$ $0.05)$ the intercept and slope parameters are also provided with standard errors of the parameters estimates in parentheses.

\begin{tabular}{|c|c|c|c|c|c|c|}
\hline Region and species & $\mathrm{n}$ & $\mathrm{F}$ & $\mathrm{P}$ & $\mathrm{R}^{2}$ & Intercept (se) & Slope (se) \\
\hline \multicolumn{7}{|l|}{ Boreal - Finland } \\
\hline Betula pendula & 14 & 2.607 & 0.132 & & & \\
\hline Picea abies & 16 & 0.634 & 0.439 & & & \\
\hline Pinus sylvestris & 16 & 1.773 & 0.204 & & & \\
\hline All combined & 46 & 0.001 & 0.972 & & & \\
\hline \multicolumn{7}{|l|}{ Hemiboreal - Poland } \\
\hline Betula pendula & 21 & 0.060 & 0.809 & & & \\
\hline Carpinus betulus & 22 & 1.523 & 0.232 & & & \\
\hline Picea abies & 22 & 0.103 & 0.752 & & & \\
\hline Pinus sylvestris & 22 & 0.183 & 0.674 & & & \\
\hline Quercus robur & 23 & 7.249 & 0.014 & 0.26 & $3.19(0.90)$ & $-0.44(0.17)$ \\
\hline All combined & 110 & 0.622 & 0.432 & & & \\
\hline \multicolumn{7}{|l|}{ Temperate Beech - Germany } \\
\hline Acer pseudoplatanus & 18 & 0.278 & 0.606 & & & \\
\hline Fagus sylvatica & 25 & 0.017 & 0.897 & & & \\
\hline Fraxinus excelsior & 19 & 0.019 & 0.891 & & & \\
\hline Picea abies & 9 & 0.138 & 0.721 & & & \\
\hline Quercus petraea & 16 & 2.265 & 0.156 & & & \\
\hline All combined & 87 & 0.021 & 0.885 & & & \\
\hline \multicolumn{7}{|l|}{ Mountainous Beech - Romania } \\
\hline Abies alba & 13 & 0.942 & 0.353 & & & \\
\hline Acer pseudoplatanus & 10 & 0.291 & 0.604 & & & \\
\hline Fagus sylvatica & 17 & 1.280 & 0.276 & & & \\
\hline Picea abies & 12 & 2.116 & 0.176 & & & \\
\hline All combined & 52 & 3.613 & 0.063 & & & \\
\hline \multicolumn{7}{|l|}{ Thermophilous deciduous - Italy } \\
\hline Castanea sativa & 15 & 0.181 & 0.677 & & & \\
\hline Ostrya carpinifolia & 15 & 0.066 & 0.801 & & & \\
\hline Quercus cerris & 18 & 3.125 & 0.096 & & & \\
\hline Quercus ilex & 19 & 0.104 & 0.751 & & & \\
\hline Quercus petraea & 16 & 2.623 & 0.128 & & & \\
\hline All combined & 83 & 1.071 & 0.304 & & & \\
\hline \multicolumn{7}{|c|}{ Continental-Mediterranean - Spain } \\
\hline Pinus nigra & 12 & 1.299 & 0.281 & & & \\
\hline Pinus sylvestris & 12 & 0.684 & 0.427 & & & \\
\hline Quercus faginea & 12 & 0.196 & 0.667 & & & \\
\hline All combined & 36 & 0.098 & 0.756 & & & \\
\hline
\end{tabular}


Drought responses by individual tree species are not often correlated with tree species diversity in European forests

David Forrester, Damien Bonal, Seid Dawud, Arthur Gessler, André Granier, Martina Pollastrini, Charlotte Grossiord

Table S5. Summary statistics for the relationships between $\Delta \delta^{13} \mathrm{C}(\%)$ and soil $\mathrm{C} / \mathrm{N}$ for each species and all data combined. When the relationships were significant $(\mathrm{P}<0.05)$ the intercept and slope parameters are also provided with standard errors of the parameters estimates in parentheses.

\begin{tabular}{|c|c|c|c|c|c|c|}
\hline Region and species & $\mathrm{n}$ & $\mathrm{F}$ & $P$ & $\mathrm{R}^{2}$ & Intercept (se) & Slope (se) \\
\hline \multicolumn{7}{|l|}{ Boreal - Finland } \\
\hline Betula pendula & 14 & 5.251 & 0.041 & 0.30 & $-0.80(1.19)$ & $0.12(0.05)$ \\
\hline Picea abies & 16 & 0.104 & 0.752 & & & \\
\hline Pinus sylvestris & 16 & 1.223 & 0.287 & & & \\
\hline All combined & 46 & 0.112 & 0.740 & & & \\
\hline \multicolumn{7}{|l|}{ Hemiboreal - Poland } \\
\hline Betula pendula & 21 & 0.129 & 0.724 & & & \\
\hline Carpinus betulus & 22 & 0.122 & 0.730 & & & \\
\hline Picea abies & 22 & 2.156 & 0.158 & & & \\
\hline Pinus sylvestris & 22 & 2.551 & 0.126 & & & \\
\hline Quercus robur & 23 & 0.122 & 0.730 & & & \\
\hline All combined & 110 & 0.089 & 0.766 & & & \\
\hline \multicolumn{7}{|l|}{ Temperate Beech - Germany } \\
\hline Acer pseudoplatanus & 18 & 0.295 & 0.595 & & & \\
\hline Fagus sylvatica & 25 & 0.754 & 0.394 & & & \\
\hline Fraxinus excelsior & 19 & 3.039 & 0.099 & & & \\
\hline Picea abies & 9 & 0.481 & 0.510 & & & \\
\hline Quercus petraea & 16 & 0.377 & 0.377 & & & \\
\hline All combined & 87 & 0.417 & 0.520 & & & \\
\hline \multicolumn{7}{|l|}{ Mountainous Beech - Romania } \\
\hline Abies alba & 13 & 0.520 & 0.486 & & & \\
\hline Acer pseudoplatanus & 10 & 0.511 & 0.495 & & & \\
\hline Fagus sylvatica & 17 & 3.893 & 0.067 & & & \\
\hline Picea abies & 12 & 5.227 & 0.045 & 0.34 & $3.91(1.51)$ & $-0.27(0.12)$ \\
\hline All combined & 52 & 1.417 & 0.240 & & & \\
\hline \multicolumn{7}{|l|}{ Thermophilous deciduous - Italy } \\
\hline Castanea sativa & 15 & 0.024 & 0.880 & & & \\
\hline Ostrya carpinifolia & 15 & 0.258 & 0.620 & & & \\
\hline Quercus cerris & 18 & 1.675 & 0.214 & & & \\
\hline Quercus ilex & 19 & 0.082 & 0.779 & & & \\
\hline Quercus petraea & 16 & 0.000 & 0.984 & & & \\
\hline All combined & 83 & 2.158 & 0.146 & & & \\
\hline \multicolumn{7}{|c|}{ Continental-Mediterranean - Spain } \\
\hline Pinus nigra & 12 & 0.592 & 0.459 & & & \\
\hline Pinus sylvestris & 12 & 0.010 & 0.921 & & & \\
\hline Quercus faginea & 12 & 0.292 & 0.601 & & & \\
\hline All combined & 36 & 0.005 & 0.944 & & & \\
\hline
\end{tabular}

